\title{
Options and prospects of underground storage of carbon dioxide in the Slovak Republic
}

\author{
J. Pinka ${ }^{1}$, I. Plučinský, O. Susak ${ }^{2}$ \\ ${ }^{I}$ Technical University of Košice; \\ Letná 9, 04200, Košice, Slovak Republic \\ ${ }^{2}$ Ivano-Frankivsk National Technical University of Oil and Gas; \\ 15, Karpatska Str., Ivano-Frankivsk, 76019, Ukraine
}

Received: 09.06.2016 Accepted: 05.07.2016

\begin{abstract}
This paper describes an overview of particular solutions and approaches to dealing with the issue of carbon dioxide storage options in the Slovak Republic. It also deals with the options of capture and subsequent storage of carbon dioxide in underground geological formations. The Carbon Capture and Storage (CCS) technology, which seems to be very promising in this context, is one of such technologies. Smaller or larger CCS projects are carried out in different countries around the world. This contribution emphasizes the overview of solutions and approaches to the issue of dealing with $\mathrm{CO}_{2}$ and options of its storage in Slovakia. Concept of $\mathrm{CO}_{2}$ storage in deep geological formations has both its supporters and opponents. Global climate changes will likely be a very important factor that could significantly change the life conditions on the Earth.
\end{abstract}

Keywords: Carbon Capture and Storage, Carbon Dioxide, coal seams, depleted hydrocarbon deposits, salt deposits.

\section{Introduction}

Various debates on the effects of greenhouse gases on the global warming affecting the Earth are held nowadays. According to many climatologists, there is no doubt that humans and their activities, particularly in the form of increasing greenhouse gases (such as carbon dioxide), are the main factors of the increasing average annual temperature. According to the so-called climate sceptics, however, the natural cycles, such as the fluctuation of solar activity, are the main cause of global warming. A theory about whether a thing like global warming even exists is worth thinking [1-3].

\section{Carbon dioxide storage}

For energy storage gases there are usually used high volume underground tanks or above ground pressure tanks including tanks for storage of liquid gases [4]. Various methods, which are used for carbon dioxide storage in suitable geological formations below the Earth's surface, are currently under investigation.This technology is called CCS (Carbon Capture and Storage).

Injection of $\mathrm{CO}_{2}$ into underground geological formations is the basis of the carbon dioxide storage method. Geological structures offer enormous capacities so that global emissions of carbon dioxide could be

* Corresponding author: jan.pinka@tuke.sk

(C) 2016, Ivano-Frankivsk National Technical University of Oil and Gas.

All rights reserved. stored over tens or even hundreds of years. The largest storage quantities are offered by these potential storage sites:

depleted oil and natural gas fields

coal seams

deep saline aquifers (Fig. 1).

The total capacity of particular storage options is listed in Table 1 [5].

Table 1 - The global capacity of particular carbon dioxide storage options [5]

\begin{tabular}{|l|c|}
\hline \multicolumn{1}{|c|}{ Type of structure } & $\begin{array}{c}\text { Storage capacity } \\
\text { in } \mathrm{Gt} \text { of } \mathrm{CO}_{2}\end{array}$ \\
\hline Deep saline aquifers & $400-10000$ \\
\hline Depleted oil and natural gas fields & 930 \\
\hline Coal seams & 30 \\
\hline
\end{tabular}

There is a precondition that these sites must be located sufficiently deep down below the surface, where there are such strong pressures that would keep carbon dioxide in liquid state of matter. Otherwise, it would expand, find access to the surface and leak into the atmosphere [5].

Options for $\mathrm{CO}_{2}$ storage in depleted oil and natural gas fields

The first method, which has successfully been implemented for several years, is $\mathrm{CO}_{2}$ storing in depleted oil and natural gas fields. This idea came up in connection with ultimate recovery of the last remaining raw materials from fields using the overpressure method. Thus, depleted oil or natural gas fields, in which yield of the residual petroleum can possibly be 


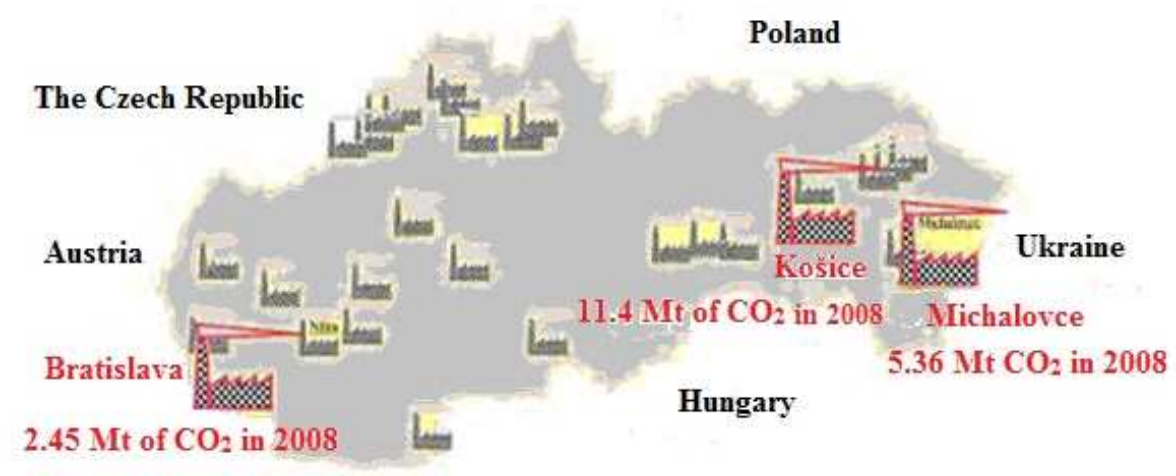

Figure 1 - The large pollution sources with estimated carbon dioxide production exceeding $1 \mathrm{Mt}$ of $\mathrm{CO}_{2}$ in 2010 together with the major regional sources [5]

enhanced by using $\mathrm{CO}_{2}$ injection (it is the so-called EOR method, the Enhanced Oil Recovery) by 10 to $15 \%$ (Fig. 3), are the potential storage sites [7-10].

Ideally, enhanced petroleum yield can eliminate the costs of $\mathrm{CO}_{2}$ capture and storage. This method has been applied for several decades, particularly in the United States. Two objectives are achieved this way (Fig. 2): $\mathrm{CO}_{2}$ storage and enhancement of petroleum yield making the methodology cost-effective. The following basic conditions must be met in the abovementioned cases:

minimum depth of the storage site must be approximately $800 \mathrm{~m}$ below the Earth's surface, where carbon dioxide is in the so-called super critical state that is represented by a pressure of $0.74 \mathrm{MPa}$ ( 7.4 bars) and a temperature of $31.1^{\circ} \mathrm{C}$. It has properties of a liquid and a gas in this state.

hanging wall of the storage area must be impermeable and undamaged (by tectonic activities or previous wells).

the sealing effect of the reservoir is required too.

Inert gas injection experience should be used to create $\mathrm{CO}_{2}$ storage. Such projects have been implemented in France [9]. The implementation process should include the following stages:

reservoir selection;

reservoir data collection and analysis;

modeling of injection.

Reservoir selection part should include the following information:

total storage capacity;

number of existing wells;

strategic importance to the company's system.

The first two criteria are based on economic and technical considerations; the last prescreening criteria are risk-based criteria that allow a company to exclude a field that has high strategic importance. During this part of the project the following features should be sought and evaluated:

high base gas fraction;

high structural closure;

isolated area for $\mathrm{CO}_{2}$ placement;

large downdip area;

thin reservoir;

favorable porosity and permeability in the probable $\mathrm{CO}_{2}$ injection zone;

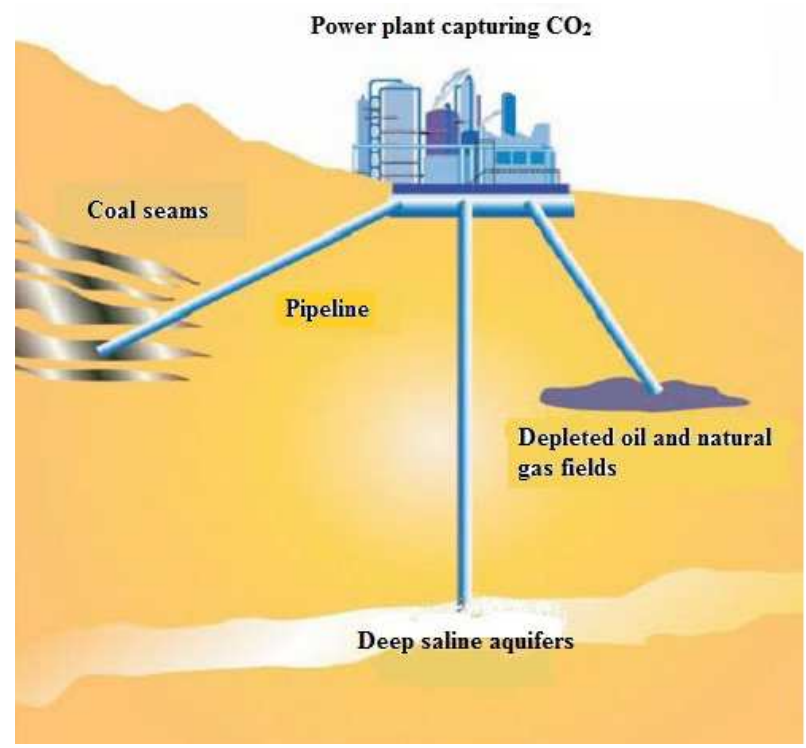

Figure 2 - Ways and options for $\mathrm{CO}_{2}$ storage [8]

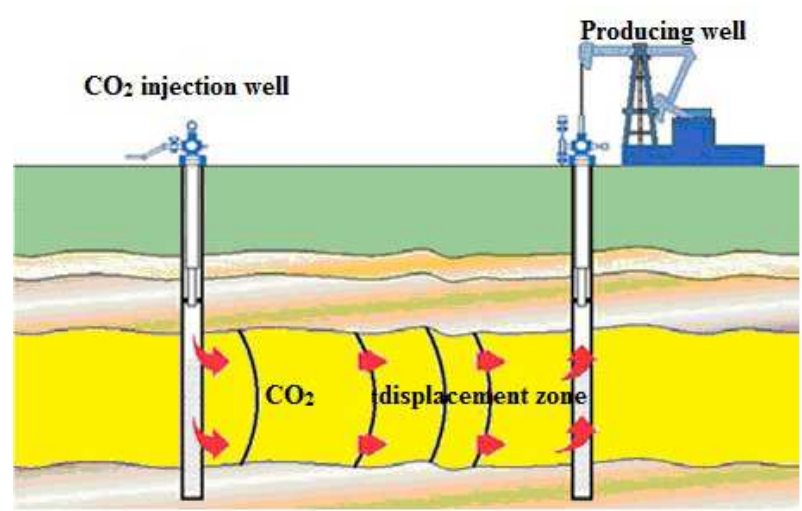

Figure 3 - Scheme of $\mathrm{CO}_{2}$ storage by the so-called EOR method [4]

absence of large-scale heterogeneities; existence of a well (or wells) for $\mathrm{CO}_{2}$ injection; existence of wells for monitoring performance after injection;

existence of a well (or wells) for tracer testing;

availability of data for reservoir modeling.

These criteria are based on technical or technicaleconomic considerations. 
The objective of data collection is to provide data required for an engineering analysis of any potential site. Two levels of data are required. First, enough data on the site are needed to qualify the site as a promising candidate for such a project. Second, more detailed data are required to perform an engineering analysis to formulate an implementation plan for project use at a qualified site. A general description of required data is provided in this section.

Most of these data are required to provide input to reservoir models and can be put into the following categories [11-18]:

reservoir data;

fluid data;

performance history data;

dispersion data.

Defining the reservoir includes detailed geological data (e.g., depth to the top of the structure, net thickness, position of a gas/water contact, extent and strength of any associated aquifer, and the degrees of layering of the reservoir), petrophysical information, characterization of injection/withdrawal and observation wells, and inventory data. This information is used to characterize the structural or stratigraphic trapping mechanism, establish the areal and vertical limits of the reservoir, identify the presence of lenses and pinchouts, and delineate the distribution of fluids in the reservoir. Sources of this category of information consist primarily of well logs, analyses of core and/or cuttings from wells, well completion and testing information. Seismic data, if available, can be used in defining structure and stratigraphy. Knowledge of regional geology helps in filling data gaps by extrapolation/interpolation in areas where well data are sparse.

The desired petrophysical data include porosity, water saturation, permeability, relative permeability, capillary pressure, and rock compressibility. These data are used to compute gas-in-place; to describe spatial variations of porosity, water saturation, and permeability; and to determine the transmissivity of reservoir fluids. Primary sources of these data are well logs, well testing, and core analyses [18-20].

Characterization of wells includes compiling information on exact bottom-hole location, size of tubulars, type of completion, completed interval, flow potential, skin (damage or stimulation), and workover history. These data are essential for reservoir simulation and can be found in well files. The required inventory data include an estimate of total gas in the field as a function of time and as determined by volumetric and material balance methods. The purpose of this exercise is not only to determine the integrity of the storage field but also to generate confidence in the estimated size of the storage reservoir. If gas has been lost from the field, there is also needed an estimate of when and how much.

Fluid data required include viscosity, compressibility, and density for gas and liquid phases. For both phases, these properties are input as a function of pressure. Primary sources for these data are periodic sample analyses for fluids produced and/or injected. It is not uncommon to simply have compositional analyses performed on samples.
Historical pressure/withdrawal data are an important part of a reservoir simulation study. The specific data desired include injection and withdrawal rates, flowing and static well pressures. Ideally, injection and withdrawal rates will be available for each well. Alternatively, injection and withdrawal rates may be available on a field-wide basis only. Allocation of field-wide rates to individual wells requires knowledge of well performance, pressures in the gathering systems and in the reservoir, and the usage pattern of wells by the operator. Periodic backpressure tests on wells provide an excellent basis for allocation of field-wide flow rates. Liquid production rates should be obtained as well. These data are used for history matching purposes to refine the description of the reservoir. Generally, flow rate data are input to the model, and the computed pressure data are compared with actual measured pressures as functions of both time and position in the reservoir.

For such studies we can use extensive experience in the analysis of cyclic operation of underground gas storage in Western Ukraine [21-23].

The degree to which $\mathrm{CO}_{2}$ and natural gases mix in a gas storage reservoir will have a large impact on the design of any $\mathrm{CO}_{2}$ project. Reservoir heterogeneities of all scales (from variations in individual pore throat dimensions to larger scale areal and vertical variations in rock properties) do affect mixing and must be accounted for in the reservoir simulation to arrive at a meaningful $\mathrm{CO}_{2}$ injection strategy. The best method of estimating the dispersion coefficient is to perform a tracer test a direct measurement of dispersion on the reservoir in an area of the field where the $\mathrm{CO}_{2} /$ natural gas interface is expected to be. A tracer test involves the injection of natural gas spiked with a small concentration of tracer gas. The concentration of the tracer is then monitored as it mixes with untraced gas in the reservoir.

The objective of the modeling is to describe the static (reservoir pore volume) and dynamic (changes in reservoir pressures as a result of storage inject/ withdrawal operations) characteristics of the storage reservoir and any associated aquifer. The final reservoir description arrived at by the engineering analysis should be able to predict the long-term performance of the gas storage in the presence of $\mathrm{CO}_{2}$ project. The results of the engineering analysis will be used in the detailed risk assessment for assigning probabilities to the event tree.

As the calculations are too complex to be done by conventional tools of reservoir engineering, mathematical models are used to describe the physical processes occurring in a reservoir. The equations used in such models are generally non-linear and require numerical solutions using a computer program.

\section{Options for $\mathrm{CO}_{2}$ storage in depleted coal deposits}

One of the options for $\mathrm{CO}_{2}$ storage is nonproduced or abandoned coal seams. Deep coal seams can not sometimes be mined because they are too thin or placed too deep, which reduces their economic importance. However, they usually contain a certain 
amount of methane [5]. Coal can absorb carbon dioxide very well. Therefore, it makes suitable environment for its storage. Gaseous $\mathrm{CO}_{2}$ is injected through wells, flows through a porous coal system, is dispersed into the coal seam and is adsorbed into the micro pores (Fig. 4). Forcing $\mathrm{CO}_{2}$ into coal seams showed that $\mathrm{CO}_{2}$ bonded coal better than methane, which resulted in release of methane. The coal seam produces methane, which can be used economically, due to the placement of carbon dioxide. Since coal seams had been storing methane for tens of millions of years, it is very likely that they will similarly bond $\mathrm{CO}_{2}$ for next tens of thousands of years. The $\mathrm{CO}_{2}$ storage in coal seams is subject to: dioxide.

the physical properties of the stored carbon

the physical properties of coal.

the geological characteristics of the potential storage site.

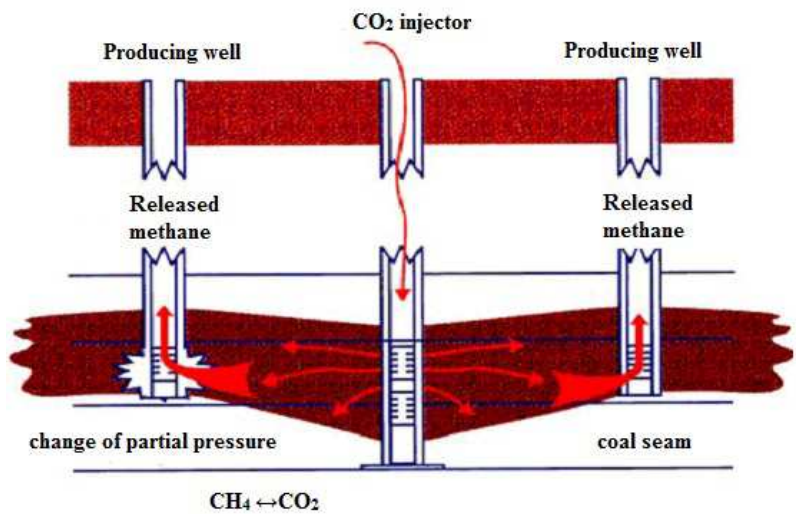

Figure 4 - Scheme of coal methane displacement by $\mathrm{CO}_{2}$ injection into coal seams [4]
$\mathrm{CO}_{2}$ storage options in the Slovak Republic

Although the sites in the Vienna Basin are considered to be the most suitable for this purpose, they are and will probably be used for natural gas storage even in the future. A feasibility study of hydrocarbon deposits located in Eastern Slovakia, which are situated near several producers of carbon dioxide, is currently being prepared. The sites are, for example, Senné, Stretava, Pozdišovce - Trhovište. There are also smaller potential storage sites such as Bánovce nad Ondavou, Ptrukša, Višňov, Trebišov and Kravany (Fig. 5). The total potential storage capacity of these areas is $49.9 \mathrm{Mt}$ of $\mathrm{CO}_{2}$. Since the Senné storage site was considered as a possible future natural gas underground storage facility, it appears to be the most promising out of all for the purpose of carbon dioxide storage. It was found out that this area can store about $15.2 \mathrm{Mt}$ of $\mathrm{CO}_{2}$. An important factor when considering the storage in these sites is the fact that several large $\mathrm{CO}_{2}$ sources, such as Vojany - an annual $\mathrm{CO}_{2}$ production of over $2.6 \mathrm{Mt}$ and the compressor station of Vel'ké Kapušany $-\mathrm{CO}_{2}$ production of $0.45 \mathrm{Mt}$, are located only a few kilometres from these potential $\mathrm{CO}_{2}$ storage sites. On the other hand, these suitable storage structures are located in populated areas, and therefore the residents will naturally try to avoid having a facility like this near their homes.

Another option, which can be used to store carbon dioxide in Slovakia, is coal seams (Fig. 6). The potential storage sites of this type are located there where coal is currently extracted in the Slovak Republic. Theoretically, these areas will be available for $\mathrm{CO}_{2}$ storage after having been depleted. These sites include Nováky, Handlová, Cígel', which are located in the Upper Nitra Basin. Another important area of brown coal occurrence is located in the South Slovak Basin, where there are verified coal seams in the Modrý Kameň, Horné Strháre, L'uboriečka, Žihl'ava, Červeňany

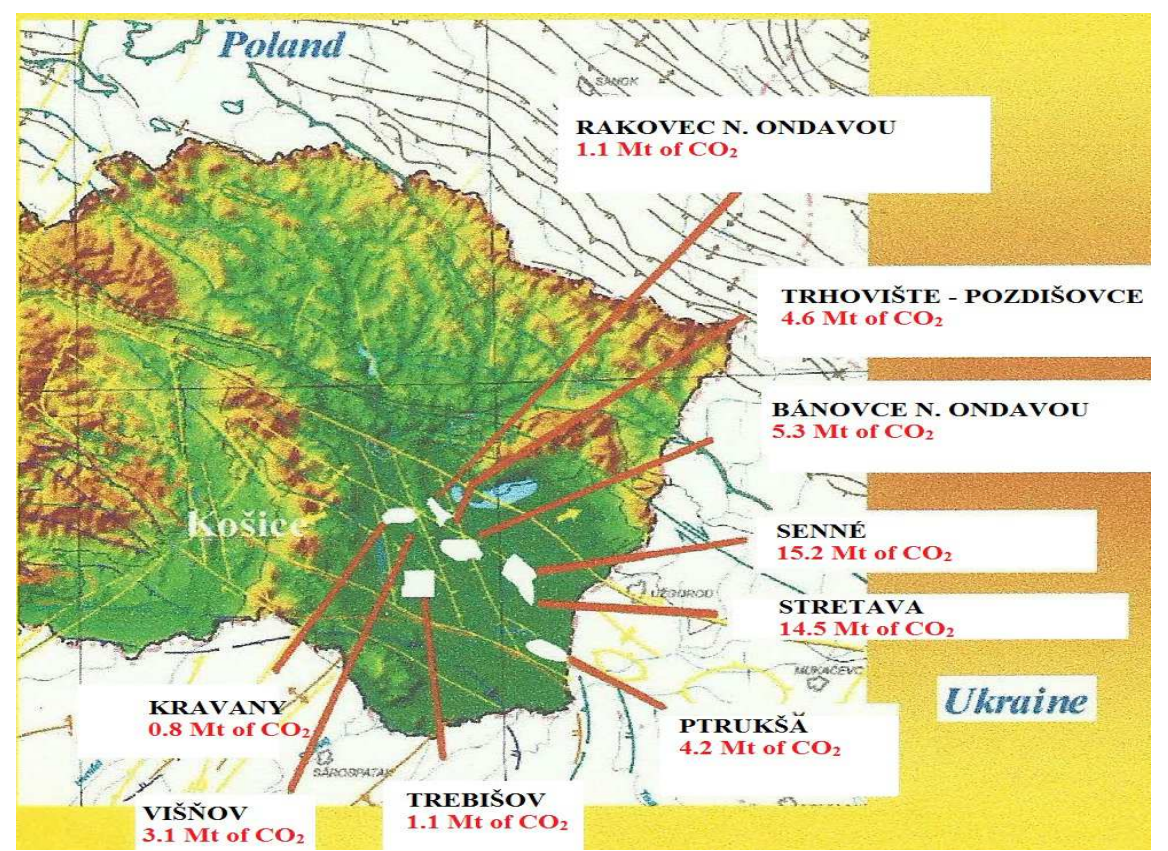

Figure 5 - Options for $\mathrm{CO}_{2}$ storage into the depleted hydrocarbon fields in the Eastern Slovak Neogene Basin [6] 


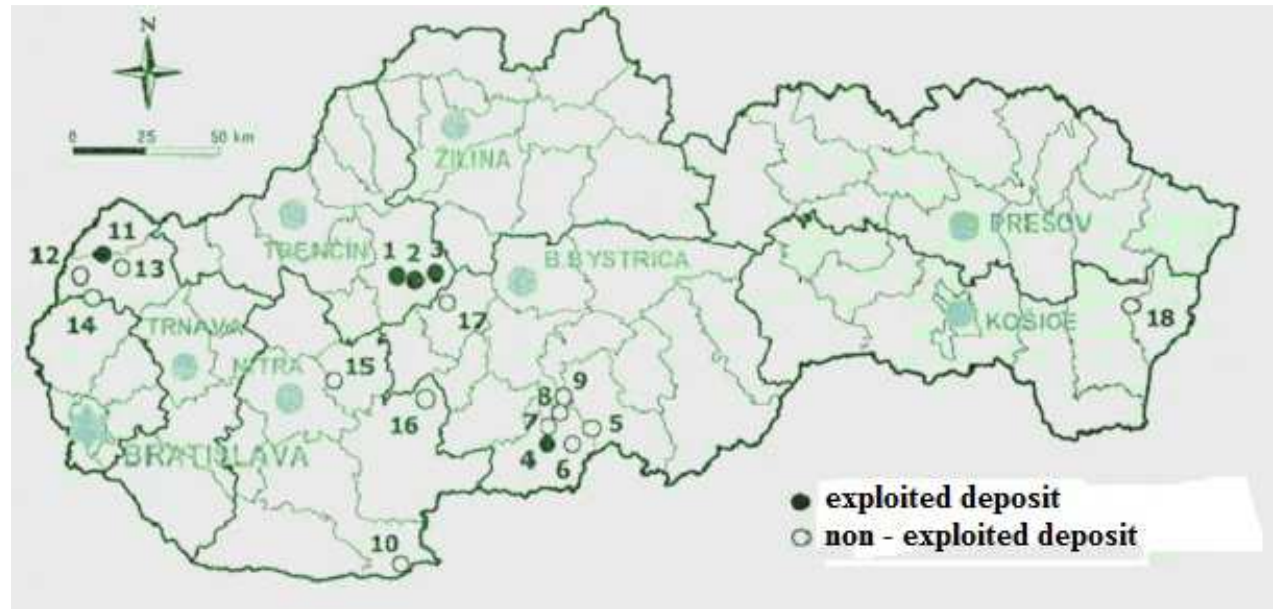

The following exclusive brown coal and lignite deposits are registered in Slovakia:

Brown coal: 1st Nováky, 2nd Cigel', 3rd Handlová, 4th Modrý Kameň, 5th L'uboriečka, 6th Žihl'ava, 7th Horné Strháre, 8th Vel'ký Lom, 9th Červeňany, 10th Štúrovo-Obid;

Lignite: 11th Gbely, 12th Kúty, 13th Štefanov, 14th Lakšárska Nová Ves, 15th Beladice, 16th Pukanec, 17th Kosorín, 18th Hnojné

Figure 6 - Brown coal and lignite deposits in Slovakia [6]

and Vel'ký Lom deposits, in the Lower Miocene. There is a known brown coal deposit, Stúrovo (Obid), in the Danube Basin, in the Štúrovský Palaeogene. Lignite deposits located in the Slovak part of the Vienna Basin, Gbely - Kúty, where the only deposit, Gbely, is extracted, are also significant. Beladice and Pukanec (Fig. 6) are famous lignite deposits in the northern part of the Danube Basin, in the Komjatice Valley. The famous deposit of Hnojné of low rank lignite seams has been located in the Eastern Slovak Basin since 1950s. There are not any verified potential storage capacities in relation to the future $\mathrm{CO}_{2}$ storage options in these deposits $[5,6,10]$.

The largest producers of carbon dioxide $\mathrm{CO}_{2}$ in 2013 are mainly companies which are located mainly in the territory of Eastern Slovakia (see Fig. 7). From an economic point of view it would be stored carbon dioxide into the excavation hydrocarbon deposits rights in the territory in the eastern part of Slovakia.

\section{Conclusions}

The notion of $\mathrm{CO}_{2}$ storage in deep geological structures also has its opponents. Some of them claim and are convinced that this is a dead end of technological development, particularly because it is very energy demanding. They argue that the CCS technology is mostly promoted by particular mining, petroleum and natural gas exploration and production companies. The mining companies see carbon dioxide-emission reduction like a way to continue mining and burning of coal, the latter like the opportunity for increasing usage of oil and natural gas fields. Their other objection is a fact that the CCS technology is not sustainable; it allows putting off solving the current problems to the future and that technology itself causes other problems. They argue that the financial means, which would be invested in the development and operation of the CCS technology, would drain off a portion of the allocated financial

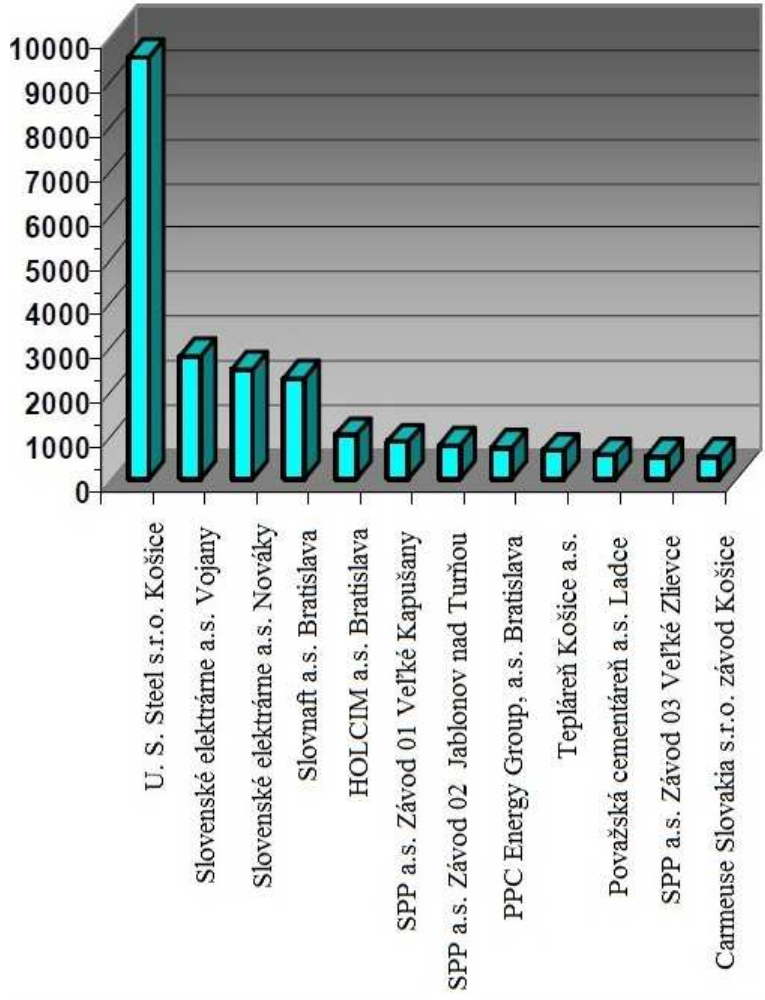

Figure 7 - The largest producers of carbon dioxide $\mathrm{CO}_{2}$ in Slovakia (Mt / year)

means for other methods of $\mathrm{CO}_{2}$ emissions reduction; in particular for the equipment and energy efficiency development and renewable energy sources, which are potentially more sustainable. The issue of very energy demanding operation of the CCS technology is mainly worth considering. Global climate changes will likely be a very important factor that could significantly change life conditions on the Earth. According to our opinions and due to the aforementioned fact, it is necessary for a part of science research to focus on the issues of carbon dioxide capture and storage. 


\section{References}

[1] Pinka, J 2014, Glossary of Oil and Gas Terms: Monograph, Ostrava.

[2] Pinka, J, Wittenberger, G \& Engel, J 2007, Borehole mining: University textbook, ES F BERG TU Košice. (in English).

[3] Pinka, J, Urbanová, T, Harčárová, M \& Šurim, J 2011, 'Possibilities and prospects of carbon dioxide $\mathrm{CO}_{2}$ storage in the Slovak Republic', in Situation in Ecologically Loaded Regions of Slovakia and Central Europe: proceeding from the XX Scientific Symposium with International Participation, October 20-21 2011, UGt SAV Košice, pp.7886.

[4] Pinka, J \& Marcin, M 2004, 'Option for the storage of toxic and radioactive waste in salt deposits in Slovakia, using a combination of wells and salt caverns', Acta Montanistica Slovaca, no. 3, pp. 236-239.

[5] Pinka, J \& Jágerová, B 2006, 'The possibilities of heat pumps utilisation for family houses and flats fumigation', Acta Montanistica Slovaca, Roč. 11, Special issue no. 1, pp. 133-136. (in Slovak).

[6] Pinka J, Wittenberger, G \& Engel, J 2006, Borehole mining: University textbook, ES F BERG, Košice, pp. 1- 227. (in Slovak).

[7] Bert, $M$ et al. 2005, 'Special Report on Carbon Dioxide Capture and Storage', IPCC, Cambridge University Press, Cambridge, United Kingdom and New York, USA, pp. 1-442.

[8] Baines, SJ \& Worden, RH 2004, Geological storage of carbon dioxide, Geological Society, $264 \mathrm{p}$.

[9] Ellis, PF, Harrison, MR \& Weiss, WL 1997, Guidelines For Implementation And Risk Assessment Of Inert Base Gas Projects: Final Report October 1995. Available from [April 1997].

[10] Pinka, J \& Bauer, V 2011, 'Importance of domestic energy raw materials for energy policy and the needs of the Slovak Republic', in History and current status of mining sector in eastern Slovakia: proceedings from the Conference, 30-31.03.2011, Solivary, pp. 228-238.

[11] Thomas, DC \& Benson, S 2005, Carbon dioxide capture for storage in deep geologic formation, Elsevier.
[12] Pinka, J 2013, Exploration and extraction of unconventional oil and gas: Monograph, TU VŠB Ostrava, Ostrava. (in Slovak)

[13] Pinka, J 2013, Fundamentals of Petroleum Engineering: Monograph, TU VŠB Ostrava, Ostrava. (in Slovak)

[14] Pinka, J 2010, Methods of coiled tubing drilling, benefits and limitations of CTD, TU Košice, Košice. (in Slovak)

[15] Pinka, J 2010, The technical equipments used in coiled tubing drilling technology, F BERG TU in Košice, Košice. (in Slovak)

[16] Pinka, J at all. 2001, New technologies of rocks disintegration at drilling: University textbooks, Elfa Publishing Košice, Košice.

[17] Pinka, J at all 2004, Drilling directional, horizontal and multilateral wells, Technical University in Ostrava, Czech republic, Ostrava.

[18] Pinka, J \& Marcin, M 2002, 'Underbalance drilling - its advantages and limitations in drilling practice': proceedings of the XI International Conference, Podbánské, pp. 109-114.

[19] Pinka, J \& Sidorová, M 2002, 'Generation of sand control filters in the well completion': proceedings of the XI International Conference, Podbánské, pp. 115-118.

[20] Pinka, J, Sidorová, M \& Dudla, NA 2009, Drilling rigs and their diagnostics: Monograph, EQUILIBRIA Publishing Košice, Košice.

[21] Himer, P, Susak, O \& Pechorin, O 2000, 'Use of inert gases in the operation of exhausted gas fields', in Problemy naukowo-badawcze i irozwojowe pozukiwan i eksploatacji zloz gazu ziemnego i ropy naftowej: Wydanie konferencyjne, Krakow, pp. 761-764. (in Russian).

[22] Cherednichenko, D, Savkiv, B, Derkach, M, Himer R, Himer, P \& Susak, O 2003, 'Project of partial replacement of buffer gas volume with nitrogen of the UGS Dashavske', in VNIIGAZ at the turn of the century - the science of the gas, gas technologies: proceedings of the International Conference, Moscow, pp. 18-19. (in Russian).

[23] Himer, R, Himer, P, Derkach, M, Savkiv, B \& Susak, O 2004, 'Project of partial replacement of buffer gas volume with nitrogen of the UGS Dashavske', Scientific Bulletin of Ivano-Frankivsk National Technical University of Oil and Gas, no. 2(8), pp. 42-44. (in Ukrainian).

УДК 622.691.24

\title{
Можливості та перспективи підземного зберігання вуглекислого газу в Словацькій Республіці
}

\author{
Я. Пінка ${ }^{1}$, І. Плюшински ${ }^{1}$, О. Сусак ${ }^{2}$ \\ ${ }^{1}$ Технічний університет в м. Кошице; \\ Лєтня 9, 04200, Кошище, Республіка Словакія \\ ${ }^{2}$ Івано-Франківський національний технічний університет нафти і газу; \\ вул. Карпатська, 15, м. Івано-Франківськ, 76019, Украӥна
}

В статті подано огляд конкретних рішень і підходів до вирішення питання про можливості зберігання двоокису вуглецю у Словаччині. Розглянуто також шляхи уловлювання і подальшого зберігання вуглекислого газу в підземних геологічних формаціях. Технологія уловлювання і зберігання вуглецю (УЗВ), яка здається досить перспективною в даному контексті, - одна $з$ таких технологій. В різних країнах світу виконують великі і малі проекти з УЗВ. Це зумовлює важливість пошуку рішень та підходів до питання $\mathrm{CO}_{2}$ і можливостей його зберігання в Словаччині. Концепція зберігання $\mathrm{CO}_{2}$ в глибоких геологічних формаціях має прихильників та противників. Глобальні зміни клімату - дуже важливий фактор, який може суттєво змінити умови життя на Землі.

Ключові слова: виснажені родовищза вуглеводнів, вугільні пласти, двоокис вуглецюю, соляні родовища, уловлювання та зберігання вуглеию. 